\title{
FAKTOR-FAKTOR YANG MEMPENGARUHI REVALUASI ASET TETAP PADA PERUSAHAAN MANUFAKTUR YANG TERDAFTAR DIBURSA EFEK INDONESIA
}

\author{
Meidi Yanto \\ (Dosen STIE Pembangunan) \\ meidiyantostie@gmail.com \\ Tri Novita sari \\ (Prodi S1 Akuntansi STIE Pembangunan) \\ trinovitas@gmail.com
}

\begin{abstract}
Abstrak : Tujuan penelitian ini untuk mengetahui pengaruh Laverage, Arus Kas Operasi, Ukuran Perusahaan, Fixed Asset Intensity dan Market to Book Ratio pada Perusahaan Manufaktur yang Terdaftar di Bursa Efek Indonesia. Hasil penelitian ini menunjukkan bahwa ukuran perusahaan berpengaruh signifikan terhadap keputusan melakukan revaluasi. Laverage, arus kas kas operasi, fixed asset intensity dan market to book ratio tidak berpengaruh terhadap keputusan melakukan revaluasi aset tetap. Kesimpulan penelitian ini adalah perusahaan yang memiliki ukuran perusahaan yang tinggi cenderung untuk melakukan revaluasi aset tetap.

Kata kunci : Laverage, Arus Kas Operasi, Ukuran Perusahaan, Fixed Asset Intensity, Market to Book Ratio dan Revaluasi

Abstract : The purpose of this study was to determine the effect of Laverage, Operating Cash Flow, Company Size, Fixed Asset Intensity and Market to Book Ratio on Manufacturing Companies Listed on the Indonesia Stock Exchange. The results of this study indicate that the size of the company significantly influences the decision to revaluate. Leverage, operating cash flow, fixed asset intensity and market to book ratio do not influence the decision to revaluate fixed assets. The conclusion of this research is that companies that have high company size tend to revaluate fixed assets.
\end{abstract}

Keyword : Leverage, Operating Cash Flow, Company Size, Fixed Asset Intensity, Market to Book Ratio and Revaluation

\section{PENDAHULUAN}

Laporan keuangan adalah suatu media yang dapat digunakan oleh perusahaan untuk menghubungkan pihak-pihak yang terkait dengan perusahaan. Laporan keuangan juga dapat digunakan sebagai bentuk pertanggungjawaban manager terhadap pemilik perusahaan atas sumber daya yang dimiliki. Informasi yang tersaji didalam laporan keuangan sangat dibutuhkan oleh investor dalam menilai suatu perusahaan, untuk itu standar akutansi sangat dibutuhkan dalam menyusun suatu laporan keuangan.

Sekarang ini ada beberapa standar yang dapat dijadikan referensi dan diadopsi di dunia yaitu Internasional Financial
Reporting Stndard (IFRS) dan US Generally Accepted Accounting Principles (US-GAAP). IFRS disusun oleh International Accounting Standard Board (IASB), sedangkan USGAAP disusun oleh Financial Accounting Standard Board (FASB). Standar akutansi yang sudah diterapkan di Indonesia terdiri dari empat standar, yaitu Standar Akutansi Keuangan (SAK), Standar Akutansi Keuangan Entitas Tanpa Akuntabilitas Publik (SAK ETAP), Standar Akutansi Keuangan Syariah (SAK Syariah), dan Standar Akutansi Pemerintahan (SAP).

Aset tetap merupakan suatu bagian yang penting dalam laporan keuangan untuk menjalankan kegiatan operasional 
perusahaan. Aset tetap dapat dinilai berdasar dari harga perolehan, dan dapat disusutkan melalui masa manfaat aset tetap itu sendiri. Sehingga penggunaan metode harga perolehan dapat dikatakan tidak efektif untuk menggambarkan keadaan nilai aset yang sebenarnya. Untuk itu suatu kebijakan akutansi selain dari harga perolehan dapat diterapkan perusahaan untuk menilai keadaan aset secara wajar dan menggambarkan keadaan yang sebenarnya, perlu dipilih suatu kebijakan akuntansi selain dari harga perolehan.

Revaluasi aset tetap hanya membenahi posisi laporan keuangan, tidak ada penambahan cash inflow dan pembagian deviden pada perusahaan. Dengan adanya perubahan satandar akutansi setelah konvergensi IFRS mengakibatkan manager perusahaan memilih salah satu metode pengukuran setelah pengakuan awal yang digunakan untuk menilai aset tetap, yaitu model biaya atau model revaluasi. Dikarenakan masih sedikitnya perusahaan go public yang melakukan revaluasi aset tetap, hal ini menjadi menarik untuk diteliti.

Berdasarkan fenomena permasalah-an tersebut, maka peneliti tertarik untuk mengangkat judul " Faktor-Faktor yang Mempengaruhi Revaluasi Asset Tetap pada Perusahaan Manufaktur yang terdaftar di BEI".

\section{Tujuan Penelitian}

Berdasarkan rumusan masalah diatas, adapun tujuan dari penelitian ini adalah sebagai berikut:

1. Untuk mengetahui pengaruh tingkat laverage terhadap revaluasi aset tetap pada perusahaan manufaktur yang terdaftar di BEI.

2. Untuk mengetahui pengaruh arus kas operasi terhadap revaluasi aset tetap pada perusahaan manufaktur yang terdaftar di BEI.
3. Untuk mengetahui pengaruh ukuran perusahaan terhadap revaluasi aset tetap pada perusahaan manufaktur yang terdaftar di BEI.

4. Untuk mengetahui pengaruh fixed asset intensity terhadap revalusi aset tetap pada perusahaan manufaktur yang terdaftar di BEI.

5. Untuk mengetahui pengaruh market to book ratio terhadap revaluasi aset tetap pada perusahaan manufaktur yang terdaftar di BEI.

\section{Kegunaan Praktis}

Penelitian ini dapat digunakan sebagai acuan atau bahan referensi dan sumber pengetahuan bagi kalangan akademik. Penelitian ini diharapkan dapat dikembangkan lebih luas lagi dipenelitian selanjutanya.

Bagi peneliti dapat menambah wawasan maupun pengetahuan peneliti khususnya dalam memahami penerapan dalam teoriteori yang telah diperoleh serta dapat lebih mengerti faktor-faktor yang mempengaruhi Revaluasi Aset Tetap pada perusahaan manufaktur yang terdaftar di Bursa Efek Indonesia.

\section{METODE PENELITIAN}

Penelitian ini berbentuk deskriptif kuantitatif yaitu penelitian yang mengungkapkan besar atau kecilnya suatu pengaruh atau hubungan antara variabel bebas yaitu, Likuiditas (X1), Arus Kas Operasi (X2), Ukuran Perusahaan (X3), Fixed Asset Intensity (X4), dan Market to Book Ratio (X5) terhadap variabel terikat yaitu, Revaluasi Aset Tetap (Y). Pendekatan yang digunakan dalam penelitian ini yaitu pendekatan kuantitatif yang menganalisis data dengan menggunakan alat statistic dalam bentuk angka-angka.

\section{Jenis Data}


Jenis data yang digunakan dalam penelitian ini menggunakan data sekunder. Data sekunder umumnya berupa bukti, catatan atau laporan historis yang telah tersusun dalam arsip yang dipublikasikan dan tidak dipublikasikan.

\section{Teknik Pengumpulan Data}

Teknik Pengumpulan data yang digunakan adalah dokumentasi dan studi pustaka.

\section{Pupulasi dan Sample}

Populasi yang digunakan adalah seluruh perusahaan yang terdaftar di Bursa Efek Indonesia yang bergerak dalam bidang manufaktur pada tahun 2015 sampai tahun 2017 yang berjumlah 144 perusahaan.

Yang menjadi sampel pada penelitian ini adalah perusahaan yang memenuhi kriteriakriteria sebagai berikut :

1. Perusahaan manufaktur yang terdaftar di Bursa Efek Indonesia selama periode 2015-2017.

2. Perusahaan yang tidak menggunakan satuan mata uang rupiah dalam laporan keuangannya.

3. Perusahaan yang tidak delisting atau keluar dari BEI selama periode penelitian.

4. Perusahaan yang laporan keuangannya tidak memilki kelengkapan informasi data - data yang terkait untuk penelitian.

Sesuai dengan kriteria diatas, maka sampel yang digunakan dalam penelitian ini adalah 93 perusahaan.

\section{Defenisi Operasional}

Revaluasi Aset Tetap (Y) adalah penilaian kembali aset tetap perusahaan. Variabel ini menggunakan dummy dengan proksi sesuai penelitian dengan ketentuan sebagai berikut:
Dummy $=1$ jika perusahaan menggunakan metode revaluasi, 0 jika perusahaan tidak menggunakan metode revaluasi.

Rasio laverage (X1) mengukur kemampuan perusahaan dalam memenuhi semua hutang jangka pendek dan jangka panjangnya.

$$
\text { Debt To Total Asset }=\frac{\text { Total Hutang }}{\text { Total Aset }}
$$

Arus kas operasi (X2) merupakan berbagai aktivitas yang berkaitan dengan upaya perusahaan untuk menghasilkan produk, sekaligus semua upaya yang terkait dalam upaya untuk memperoleh laba usaha.

$$
\text { Arus } \text { kas operasi }=\frac{\text { Arus } \text { kas operasi }}{\text { Total aset tetap }}
$$

Ukuran perusahaan (X3) merupakan suatu skala dimana perusahaan dapat diklasifikasikan berdasarkan ukuran besar kecilnya perusahaan menurut berbagai cara antara lain dengan total aset, penjualan bersih, dan kapitalisasi pasar perusahaan. Size perusahaan yang diukur dengan total aset akan ditransformasikan kedalam logaritma of natural untuk menyamakan dengan variabel lain, karena total aset perusahaan nilainya relatif besar dibandingkan dengan variabel-variabel lain. $S I Z E=L n$ total aset perusahaan

Fixed asset intensity (X4) merupakan proporsi aset perusahaan yang terdiri dari aset tetap. Fixed asset intensity mempresentasikan proporsi aset tetap dibandingkan total aset perusahaan.

$$
\text { Fixed Asset Intensity }=\frac{\text { Total Aset tetap }}{\text { Total aset }}
$$

Market to book ratio (X5) merupakan rasio perbandingan antara harga pasar perlembar saham dibandingkan dengan nilai buku perusahaan. Market to book ratio merupakan cerminan apresiasi atau penilaian investor terhadap nilai buku sebuah perusahaan melalui harga saham. Semakin tinggi market to book ratio, maka semakin 
baik pula penilaian investor terhadap nilai buku perusahaan.

$$
\begin{aligned}
& \text { Market to book ratio } \\
& =\frac{\text { Nilai pasar ekuitas perlembar }}{\text { Nilai buku ekuitas perlembar }}
\end{aligned}
$$

\section{Teknik Analisa Data}

\section{Menilai Model Fit (overall Model Fit)}

Langkah pertama yang dilakukan dalam pengujian regresi logistic adalah menilai model fit (Overall Model Fit). Hipotesis untuk menilai model fit adalah:

H0 : Model yang dihipotesakan fit dengan data

Ha : Model yang dihipotesakan tidak fit dengan data.

\section{Menilai Kelayakan Model Regresi}

Kelayakan model regresi yang dipakai dalam penelitian ini dinilai dengan menggunakan Hosmer and Lemeshow's Goodness of Fit Test. Hosmer and Lemeshow's Goodness of Fit Test menguji hipotesis nol agar sesuai dengan data empiris atau model perbedaan antara moel dengan data sehingga dapat dikatakan model fit dengan data. Jika nilai statistik Hosmer and Lemeshow's Goodness of Fit Test lebih kecil sama dengan 0,05, maka hipotesis nol ditolak.

\section{Koefisien Determinasi (R2)}

Menurut (Ghozali, 2011), Pengujian koefisien determinasi pada regresi logistic dengan menggunakan Nagelkerke's $R$ square. Nagelkerke's $R$ square merupakan modifikasi dari koefisien memodifikasi koefisien Cox dan Snell's $R$ Square untuk memastikan bahwa nilainya bervariasi dari 0 (nol) sampai 1(satu) Uji Hipotesis

Model regresi logistik yang digunakan adalah sebagai berikut:

$$
\begin{gathered}
Y=\alpha+\beta 1 \mathrm{LEV}+\beta 2 \mathrm{AK}+ \\
\beta 3 \text { SIZE }+\beta \text { 4Intensity }+\beta 5 \mathrm{MBR}+\varepsilon
\end{gathered}
$$

Keterangan :
$Y$ : Revaluasi Aset Tetap, kode 1 jika perusahaan melakukan revaluasi dan 0 jika perusahaan tidak melakukan revaluasi.

$\alpha$ : nilai koefisien konstanta

$\beta 1, \beta 2, \beta 3, \beta 4, \beta 5$ : berturut-turut untuk nilai koefisien variabel independen

LEV : Laverage

AKS : Arus Kas Operasi

SIZE : Ukuran Perusahaan

Intensity: Fixed Asset Intensity

MBR : Market to Book Ratio

\section{HASIL DAN PEMBAHASAN}

Hasil Analisa Data

Analisis Regresi Logistik

Pengujian hipotesis dilakukan dengan menggunakan regresi logistic. Model regresi ini dipilih karena variabel dependen dalam penelitian ini bersifat dichotomous.

\section{Uji Menilai Keseluruhan Model Fit (Overall Model Fi)t}

Untuk melihat model regresi yang baik serta data observasi cocok dengan model menggunakan nilai -2 Loglikehood. Dari hasil perhitungan-2 Loglikehood pada blok pertama (block number $=0$ ) didapatkan nilai -2 Loglikehood sebesar 259,011 seperti yang terlihat pada tabel 4.20 dibawah ini :

Tabel 1

\section{Iteration History}


Sumber: SPSS 21

Selanjutnya hasil perhitungan nilai -2 Loglikehood pada blok kedua (block number $=1$ ) didapat nilai -2Loglikehood sebesar 235,536.

Pada uji Overall Model Fit (Menilai Keseluruhan model) ini menggunakan -2 Loglikehood, apabila terjadi penurunan pada blok kedua (block number $=1$ ) dibandingkan dengan blok pertama (block number $=0$ ) maka dapat disimpulkan bahwa model regresi adalah regresi yang baik. Pada blok pertama (block number $=0$ ) nilai -2 Loglikehood sebesar 259,011 dan pada blok kedua (block number $=1$ ) nilai -2 Loglikehood sebesar 235,536. Dengan adanya penurunan nilai -2 Loglikehood ( block number $=0$ - block number $=1$ ) maka model diterima karena cocok dengan data dan menyimpulkan bahwa model regresi adalah regresi yang baik untuk memprediksi revaluasi aset tetap.

\section{Uji Menilai Kelayakan Model Regresi}

Kelayakan model regresi dinilai dengan menggunakan Hosmer and Lomeshow's Goodness of Fit Test lebih besar dari pada 0,05 maka hipotesis nol diterima. Artinya model dapat memprediksikan nilai observasinya dan model dapat diterima . Hasil uji Hosmer and Lomeshow's

\begin{tabular}{|ll|l|l|}
\hline Iteration & $\begin{array}{l}-2 \quad \text { Log } \\
\text { likelihood }\end{array}$ & $\begin{array}{l}\text { Coefficient } \\
\text { s }\end{array}$ \\
\cline { 4 - 4 } & & & Constant \\
\hline \multirow{3}{*}{ Step } & 1 & 259,011 & $-1,312$ \\
0 & 3 & 256,199 & $-1,552$ \\
& 4 & 256,184 & $-1,571$ \\
& 4 & 256,184 & $-1,571$ \\
\hline
\end{tabular}

Goo dne SS of Fit Test dap at dili

hat pada Tabel 2 berikut :

Tabel 2

Uji Kelayakan Model Regresi Hosmer and Lemeshow Test

\begin{tabular}{|l|l|l|l|}
\hline Step & Chi-square & Df & Sig. \\
\hline 1 & 4,123 & 8 &, 846 \\
\hline
\end{tabular}

Sumber : SPSS 21
Kelayakan model regresi dinilai dengan menggunakan Hosmer and Lomeshow's Goodness of Fit Test. Pengujian menunjukkan nilai chi-square sebesar 4,123 dengan signifikansi sebesar 0,846. Berdasarkan hasil tersebut, karena nilai signifikansi lebih besar dari 0,05 maka model dapat disimpulkan mampu memprediksi nilai observasinya atau dengan kata lain model dapat diterima.

\section{Uji Koefisien Determinasi}

Model summary dalam regresi logistic sama dengan pengujian R2 pada model regresi linear. Tujuan dari model summary adalah untuk mengetahui seberapa besar kombinasi variabel independen yaitu Laverage, Arus Kas Operasi, Ukuran Perusahaan, Fixed Asset Intensity dan Market to Book Ratio mampu menjelaskan variabel dependen yaitu Revaluasi Aset Tetap. Hasil model summary dapat dilihat pada tabel berikut:

\section{Tabel 3}

Hasil Uji Koefisien Determinasi Model Summary

\begin{tabular}{|l|l|l|l|}
\hline Step & $\begin{array}{l}-2 \quad \text { Log } \\
\text { likelihood }\end{array}$ & $\begin{array}{l}\text { Cox \& } \\
\text { Snell R } \\
\text { Square }\end{array}$ & $\begin{array}{l}\text { Nagelk } \\
\text { erke R } \\
\text { Square }\end{array}$ \\
\hline 1 & $235,536^{\mathrm{a}}$ &, 071 &, 119 \\
\hline
\end{tabular}

Berdasarkan Tabel 4.23, nilai koefisien Nagelkerke R Square sebesar 0,119 yang berarti kemampuan variabel independen menjelaskan variabel dependen sebesar $11,9 \%$ sedangkan $88,1 \%$ lainnya dijelaskan oleh variabel lainnya yang tidak menjadi objek penelitian ini.

\section{Hasil Pengujian Regresi Logistik}

Persamaan regresi logistic yang dibentuk adalah sebagai berikut : 
$\mathrm{Y}=8,363-0,004 \mathrm{LEV}-0,005$ AKS 0,004SIZE $+0,007$ Intensitas $+0,000 \mathrm{MBR}$

Dari persamaan regresi logistik diatas dapat dijelaskan sebagai berikut:

1. Hasil uji regresi logistik untuk variabel laverage diperoleh nilai signifikansi 0,425 . Apabila dibandingkan dengan $\alpha$ $5 \%$ maka nilai $0,425>0,05$ sehingga $\mathrm{H} 1$ ditolak. Hal ini menunjukkan variabel laverage tidak berpengaruh terhadap keputusan melakukan revaluasi aset tetap.

2. Hasil uji regresi logistic untuk variabel arus kas operasi diperoleh nilai signifikansi 0,154 . Apabila dibandingkan dengan $\alpha 5 \%$ maka nilai $0,154>0,05$ sehingga H2 ditolak. Hal ini menunjukkan variabel arus kas operasi tidak berpengaruh terhadap keputusan melakukan revaluasi aset tetap.

3. Hasil uji regresi logistik untuk variabel ukuran perusahaan diperoleh nilai signifikansi 0,001. Apabila dibandingkan dengan $\alpha 5 \%$ maka nilai $0,001<0,05$ sehingga H3 diterima. Hal ini menujukkan variabel ukuran perusahaan berpengaruh terhadap keputusan melakukan revalusi aset tetap.

4. Hasil uji regresi logistik untuk variabel fixed asset intensity diperoleh nilai 0,482. Apabila dibandingkan dengan $\alpha 5 \%$ maka nilai 0,482 > 0,05, sehingga $\mathrm{H} 4$ ditolak. Hal ini menunjukkan variabel fixed asset intensity tidak berpengaruh terhadap keputusan melakukan revaluasi aset tetap.

5. Hasil uji regresi logistik untuk variabel market to book ratio diperoleh nilai 0,571 . Apabila dibandingkan dengan $\alpha$ $5 \%$ maka nilai $0,571>0,05$, sehingga $\mathrm{H} 5$ ditolak. Hal ini menunjukkan variabel market to book ratio tidak berpengaruh terhadap keputusan revaluasi aset tetap.

\section{PENUTUP}

\section{Kesimpulan}

Berdasarkan hasil pengujian dan pembahasan data mengenai pengaruh
Laverage, Arus Kas Operasi, Ukuran Perusahaan, Fixed Asset Intensity dan Market to Book Ratio dapat disimpulkan sebagai berikut:

1. Laverage tidak berpengaruh signifikan terhadap revaluasi aset tetap pada perusahaan manufaktur yang terdaftar di BEI. Hal tersebut membuktikan bahwa tinngkat laverage yang tinggi tidak mempengaruhi perusahaan tersebut untuk melakukan revaluasi aset tetap.

2. Arus kas Operasi tidak berpengaruh signifikan terhadap revaluasi aset tetap pada perusahaan manufaktur yang terdaftar di BEI. Hal tersebut membuktikan bahwa perusahaan yang mengalami penurunan arus kas operasi tidak mempengaruhi perusahaan tersebut untuk melakukan revaluasi aset tetap.

3. Ukuran Perusahaan berpengaruh terhadap revaluasi aset tetap pada perusahaan manufaktur yang terdaftar di BEI. Hal ini membuktikan bahwa perusahaan dengan ukuran perusahaan yang tinggi cenderung untuk melakukan revaluasi aset tetap untuk terhindar dari meningkatnya biaya politik dan peraturan yang lebih ketat.

4. Fixed Asset Intensity tidak berpengaruh signifikan terhadap revaluasi aset tetap pada perusahaan manufaktur yang terdaftar di BEI. Hal tersebut membuktikan bahwa perusahaan dengan fixed asset intensity yang tinggi tidak mempengaruhi perusahaan tersebut untuk melakukan revaluasi aset tetap.

5. Market to Book Ratio tidak berpengaruh signifikan terhadap revaluasi aset tetap pada perusahaan manufaktur yang terdaftar di BEI. Hal tersebut membuktikan bahwa perusahaan dengan market to book ratio tinggi tidak mempengaruhi perusahaan tersebut untuk melakukan revaluasi aset tetap. 


\section{DAFTAR PUSTAKA}

Achmadi, C. N. D. . (2016). Metodologi Penelitian. Jakarta: PT. Bumi Aksara.

Ais Zakiyudin. (2013). Akutansi Tingkat

Dasar. Jakarta: Mitra Wacana Media.

Anastasia Diana, L. setiawati. (2017).

Akutansi Keuangan Menengah (satu).

Yogyakarta: C.V ANDI OFFSET.

Andrey Hasiholan Pulungan , Ahmad Basid

Hasibuan, dan L. H. (2013). Akutansi

Keuangan Dasar Berbasis PSAK Per 1

Juni 2012 (Edisi-1). jakarta: Mitra Wacana Media.

Astuti, P. D. (2012). Akutansi Keuangan

Dasar I. Yogyakarta: CAPS.

Barac, Zeljana Aljinovic dan Sodan, S. (2011). Motives For Asset Revaluation Policy Choice In Croatia, 2.

Darmawan, D. (2013). Metode Penelitian. Bandung: Rosda.

Dwi Martani, Sylvia Veronica Siregar, Ratna Wardhani, Aria Farahmita, E. T. (2016). Akutansi Keuangan Menengah Berbasis PSAK (Edisi ke-). Jakarta Selatan: Salemba Empat.

Erly, S. (2011). Perencanaan pajak. Jakarta: Salemba empat.

Fahmi, I. (2013). Analisis Laporan Keuangan. Bandung: Alfabeta.

Firmansyah, E. D. sherlita. (2012). Pengaruh Negosiasi Debt Contacts dan Political Cost terhadap perusahaan untuk Melakukan Revaluasi Aset Tetap. SNAB.

Ghozali. (2011). Aplikasi Analisis Multivariate Dengan program IBM SPSS 26. Semarang: Universitas Diponegoro. (2013). Aplikasi Analisis Multivariate dengan Program IBM SPSS 21.

Gitman, J. L. (2009). Principles of Managerial Finance. Boston: Prentice Hall.

Hanafi, M. M. (2009). Analisis Laporan Keuangan. Jakarta: Salemba Empat.
Harahap, S. S. (2008). Analisis Kritis atas Laporan Keuangan. Jakarta: Rajawali Pers.

S. S. (2009). Analisa Kritis atas Laporan Keuangan. Jakarta: PT RajaGrafindo Persada.

S. S. (2011). Teori Akutansi. Jakarta: Rajawali Pers.

Hayu Wikan Kinarsih, A. S. (2011). Pengaruh Ukuran perusahaan, Profitabilitas dan Financial Laverage terhadap Pengungkapan Tanggungjawab Sosial studi empiris pada perusahaan Manufaktur yang terdaftar di BEI tahun 2008-2010. Ekonomi Dan Bisnis, 13.

Hendra S raharjaputra. (2009). Buku Panduan Praktis Manajemen Keuangan dan Akutansi untuk Eksekutif Perusahaan. Jakarta: Salemba empat.

Hery. (2009). Teori Akutansi. Jakarta: Kencana. (2014). Akutansi Aset, Liabilitas, dan Ekuitas. Jakarta: PT Grasindo. . (2015). Analisis Laporan Keuangan. Yogyakarta: CAPS.

IAI. (2009). Pernyataan Standar Akutansi Keuangan PSAK.

Kamaludin. (2011). Manajemen Keuangan “ Konsep Dasar dan Penerapannya." Bandung: CV Mandar Maju.

Kasmir. (2011). Analisis Laporan Keuangan (edisi 1). Jakarta: PT RajaGrafindo Persada.

Katuuk, Y. C. (2013). Analisis Perencanaan Pajak Melalui RevaluasiAktiva Tetap pada PT Angkasa Pura I Bandar Sam Ratulangi. Ekonomi Manajemen Bisnis, 01.

Khairati. (2014). Pengaruh Laverage, Firm size,dan fixed Asset Intensity Terhadap Keputusan Perusahaan Melakukan Revaluasi Aset Tetap.

Latifa, C. A., \& Haridhi, M. (2016). Pengaruh Negoisasi Debt Contracts, Political Cost, Fix Asset Intensity, dan Market to Book Ratio Terhadap 
Perusahaan Melakukan Revaluasi Aset Tetap (Studi pada Perusahaan Manufaktur yang Terdaftar di Bursa Efek Indonesia Tahun 2010-2014). Jurnal Ilmiah Mahasiswa Ekonomi Akuntansi (JIMEKA), 1(2x), 166-176.

Lukman syamsudin. (2009). Manajemen Keuangan Perusahaan. Jakarta: Kencana.

Manihuruk. (2015). Analisi Faktor-faktor yang mempengaruhi pemilihan Metode Revaluasi Asset Tetap yang terdaftar di Bursa Saham Negara ASEAN.

Misbahuddin dan Iqbal Hasan. (2013). Analisis Data Penelitian dengan Statistik. Jakarta: PT. Bumi Aksara.

Munawir. (2010). Analisis Laporan Kuangan (empat). Yogyakarta: Liberty.

Prihadi, T. (2009). Deteksi Cepat Kondisi Keuangan Analisis Rasio Keuangan. Jakarta: PPM.

Robert Libby. (2008). Akutansi Keuangan. Jakarta: Salemba empat.

Rudianto. (2009). Pengantar Akutansi; Konsep dan Teknik Penyusunan Laporan Keuangan. Jakarta: Erlangga.

Scott, W. R. (2009). Financial Accounting Theori. Prentice Hall.

Su, D. S. and J. (2010). Managerial incentives Behind Fixed Assets Revaluation: Evidence From New Zealand Firm, working paper series, No.3.

Sugiyono. (2012). Memahami Penelitian Kombinasi (mixed method). Bandung: ALFABETA.

Sugiyono. (2013). Metode Penelitian Kuantitatif Kualitatif dan R\&D. Bandung: Alfabeta.

Suwartono. (2014). Dasar-Dasar Metodologi Penelitian. Yogyakarta: CV. ANDI OFFSET.

Tay. (2009). Fixed Asset Revaluation.

Waluyo. (2013). Perpajakan Indonesia. Jakarta Selatan: Salemba empat. weygandt Kieso, \& warield. (2016). Intermediate Accounting IFRS Edition. New Jersey: Jhon Wiley\& Sons Ltd.

Widjaja, I. (2009). Pengaruh firm size dan capital structure terhadap prospek saham perusahaan. Organisasi Dan Manajemen, Hlm. 21-30.

Wild, K. R. S. dan J. J. (2010). Analisis Llaporan Keuangan (Edisi-10). Jakarta: Salemba Empat.

Wiliandri, R. (2011). Pengaruh blockholder ownership dan firm size terhadap kebijakan hutang perusahaan. Ekonomi Bisnis. 